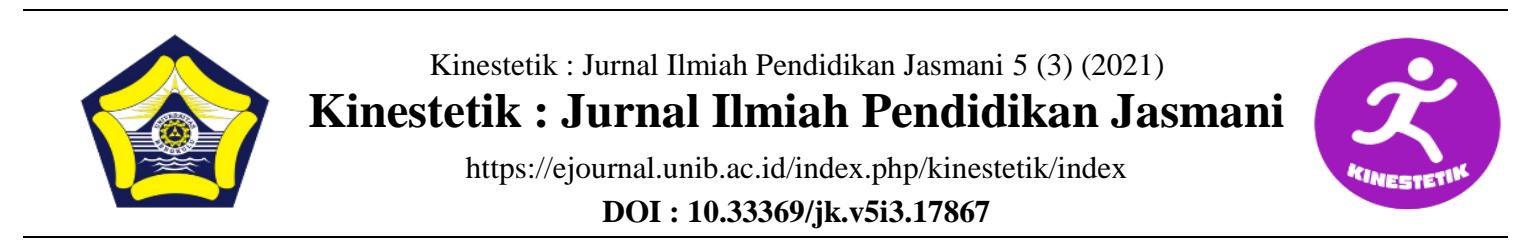

\title{
CHARACTERISTICS AND PHYSICAL FITNESS LEVELS OF STUDENTS IN WETLANDS
}

\author{
Herita Warni $^{1 *}$, Syamsul Arifin ${ }^{2}$, Ramadhan Arifin ${ }^{3}$
}

${ }^{123}$ Physical Education, Universitas Lambung Mangkurat, Indonesia

\section{Article Info}

Article History :

Received : September 2021

Revised : September 2021

Accepted : September 2021

Available online : September 2021

Keywords:

Physical Fitness, Students, Wetlands

\begin{abstract}
The purpose of this study was to determine the level of physical fitness and characteristics of students in the wetland area of Banjar Regency, South Kalimantan. The research method used is a survey method with descriptive analysis, namely data collection in the form of data on report cards for physical education lessons and interviews related to parents' income and school conditions. The study concluded that the physical fitness status of students in the wetland area in Banjar Regency, South Kalimantan was of good status but there were also students who had sufficient scores. In this sufficient category, the learning process for Physical Education, Sports and Health is constrained by ups and downs, extreme weather and field conditions that do not support activities or movements in learning.
\end{abstract}

Corresponding address : Jl. Brigjen H. Hasan Basri, Pangeran,

Kec. Banjarmasin Utara, Kota Banjarmasin, Kalimantan Selatan

*Corresponding email : hwarni@ulm.ac.id
ISSN 2685-6514 (Online)

ISSN 2477-331X (Print) 


\section{INTRODUCTION}

Improving students' physical fitness, of course, must be supported by adequate infrastructure in the school environment, as well as the ability of teachers to teach physical education. However, the ideal conditions for schools in Indonesia are not evenly distributed, as well as the ability of physical education teachers to innovate learning is still very low. Teachers tend to only carry out the teaching and learning process as a routine activity, and not all teachers have the title as professional teachers. (Jihad, 2013). Physical education as an educational process with human movement which can be in the form of physical activity, games or sports to achieve educational goals. To do so, of course, requires adequate facilities, land or space for movement must be adequate. The area of South Kalimantan is $+37,531 \mathrm{~km} 2$, the dominant area is wetlands reaching 382,272 ha. South Kalimantan Province is divided into 13 regencies/cities. One of the districts with dominant wetlands is Banjar Regency with a total area of 4,668 $\mathrm{km} 2$, with a population of 506,839 people. Dry land area $+13,757$ hectares or about $19 \%$ of the total area. Natural conditions affect cultural behavior and habits. People around the riverbanks certainly have skills in water activities, such as swimming, rowing and other things related to water. (Warni, H., Arifin, S., \& Arifin, 2020).

The lack of dry land owned by Banjar Regency has resulted in many schools being located in a wetland environment. It is recorded that the number of schools, both primary schools/ Islamic elementary schools, junior high schools, and high schools, both public and private, totaled 664 schools. From the observations, most of the schools are located in tidal wetlands with very minimal sports facilities. On the other hand, the economic status of the community is still relatively low. The dominant occupation of the community in the wetland environment of Banjar Regency is farmers, with lower middle income.

The problem of physical fitness is actually not only a problem in the wetland environment, but is a general problem in Indonesia. Low fitness is influenced by little physical activity. (Tri Irianto dan \& Arifin, 2020). Several research results show that students' fitness levels are still low. The results of research conducted by the Riskesdas (Basic Health Research) team in 2013, showed that only $17 \%$ of Indonesians had good physical fitness. This is related to the decline in participation in sports, as stated by Raden Isnanta Deputy of Sport Culture at the Ministry of Youth and Sports (Kemenpora), that in 2003-2012 there was a downward trend in participation in sports for the Indonesian people, especially those aged 10 years and over.

Many studies show that students' physical fitness is still low, but the research only revolves around certain schools or certain areas that students do on a small scale. Meanwhile, the level of physical fitness of students reported nationally has not been found. Likewise, research with the theme of fitness with a 
wetland area background has never been found except for research (Warni, H., Arifin, S., \& Arifin, 2021) which takes the Aluh-Aluh sub-district which shows that only $8.69 \%$ of students' physical fitness levels are declared good, and 33. $63 \%$ moderate levels., the rest less and less. This data shows that the physical fitness of students is very concerning, however, research on this fitness needs to be studied further. The research that will be conducted is to reveal the characteristics and problems of the implementation of Physical Education in the area where the area is predominantly wetlands.

\section{METHODS}

The research method used is a survey method with descriptive analysis, namely data collection in the form of data on report cards for physical education lessons and interviews related to parents' income and school conditions. According to (Sugiyono, 2015) Descriptive statistics are statistics used to analyze data by describing or describing the data that has been collected as it is without intending to make conclusions that apply to the public or generalizations.

\section{Participants}

The samples of this study were the students of the State Elementary School in Pagar Martapura, the State Elementary School of Astambul, State Elementary School of Alimukim, the State Elementary School of Sungai Lakum 2 and the State Primary School of Sumber Baru, totaling 100 people.

\section{Materials and Apparatus}

The instrument used in this study uses report cards and documentation. The questionnaire uses the instrument to be made, while the fitness test data collection uses the report card score instrument for physical education subjects.

\section{Procedures}

. In this study, what the researcher did was to visit the school, then do documentation and ask for report cards to see the value of physical education related to student fitness at the school. In addition, there were also interviews with parents regarding the parents' occupations and the economic level of the family as well as the problems faced by physical education teachers in carrying out the physical education learning process.

\section{Design or Data Analysis}

In this quantitative research, the data analysis technique used is descriptive statistics. According to (Sugiyono,2015), quantitative descriptive analysis technique is data analysis by describing or describing the data that has been collected as it is without intending to make conclusions that apply to the public.

\section{DISCUSSION}

The results showed that the fitness value of the public elementary school in Pagar, Martapura District in the $100 \%$ good category. Data on Physical Fitness Results of the Alimukim Public Elementary School, Pengaron District, in 
the good grade category of $83 \%$, while the average score is $17 \%$. Physical fitness data and income characteristics of parents Astambul public elementary schools, Astambul City, are in the good category, $47 \%$, while in the adequate category, $53 \%$. Physical fitness and income characteristics of parents Sungai Lakum 2 State Elementary School, Kertak District, only has a good score of $88 \%$ while the average is $12 \%$. Physical fitness data and income characteristics of the parents of the Sumber Baru State Elementary School, Sungai Pinang District are 100\% good.

Based on the results of field observations, the income characteristics of parents in all schools are farmers but some also work as teachers, private sector, stone craftsmen and others, this shows that the majority of student characteristics seen from the work of parents are farmers.

From the results of field data analysis, it can be stated that physical education learning cannot take place properly due to the constraints of the wetland environment. Facilities and infrastructure is an important and main resource in supporting teaching and learning activities in schools is very minimal. With such a lack of infrastructure, how is it possible for the physical education learning process to run smoothly. Complete and adequate infrastructure facilities support the success of physical education learning in achieving optimal physical education goals (Widiastuti, 2011).
From the results of observations and interviews, it can be stated that the average school is very minimal in ownership of sports facilities and infrastructure. However, students' interest in carrying out sports learning is quite high. (Imansyah, 2018). This high interest in sports is a factor in the success of physical education subjects, but natural factors are an obstacle to achieving this. According to (Warni, H., Arifin, S., \& Arifin, 2021) in physical education learning, facilities have an important role in learning outcomes. (Ghiffary, 2020) that in learning physical education, sports, health, facilities and facilities in learning really support student activity in learning.

From the results of the interviews, it can also be stated that physical education and health teachers are quite creative in overcoming the problems of the flooded school environment. The proof is that learning is often done in a class that is quite narrow if it is used for sports, and also often does sports on the school terrace. Physical education teachers are required to be creative (Wicaksono, 2019). Under any conditions, physical education teachers must be able to carry out physical education learning (Irawan, E., Shandi, S. A., \& Salahudin, 2020). Physical education teachers must be able to teach despite the lack of facilities in the field. (Listyarini, 2006). Besides, physical education teachers also act as demonstrators, class managers, facilitators, motivators and evaluators. (Librianty, 2020). Teachers must have 
competence as teaching readiness, besides that they are expected to have high knowledge. Therefore, in improving the quality of learning, professional teachers are needed. (Kartowagiran, 2011).

In designing learning, teachers are required to be able to utilize technology as a professional teacher. (Nurmila, 2020) (Gunawan, 2013). A teacher must be able to master field competencies, besides that professional teachers must also have moral qualities, cultured, dignified, who carry out their duties with full responsibility, fairness, conscience, discipline, obeying regulations, and being disciplined (Jihad, 2013) . In a progressive view, changes in the characteristics of society must be followed by changes in teacher culture in the learning process. Changes that are so fast require teachers to be prepared so as not to be crushed by the times, and it can even occur that students' abilities exceed the teacher's, if the teacher does not have extensive knowledge. (Arifin, M. Z., \& Setiawan, 2020).

\section{CONCLUSION}

The study concluded that the physical fitness status of students in the wetland area in Banjar Regency, South Kalimantan was of good status but there were also students who had sufficient scores. In this sufficient category, the learning process for Physical Education, Sports and Health is constrained by tides, extreme weather and field conditions that do not support activities or movements in learning. a physical education teacher is required to innovate and be creative when teaching even under any conditions.

\section{ACKNOWLEDGEMENT}

Thanks to Dean of the FKIP and Rector of Lambung Mangkurat University who have supported the writing of this article.

\section{REFERENCES}

Arifin, M. Z., \& Setiawan, A. (2020). Strategi Belajar Dan Mengajar Guru Pada Abad 21. Indonesian Journal of Instructional Technology, 1(2).

Ghiffary, M. (2020). Survei Ketersediaan Sarana dan Prasarana Penunjang Pembelajaran Pendidikan Jasmani Olahraga dan Kesehatan (PJOK) Tingkat SMP di Kecamatan Buleleng. Jurnal Ilmu Keolahragaan Undiksha, $8(1), 34-41$.

Gunawan, I. (2013). Pegembagn Pliksi Berbai Teknologi Dan Informsi Untuk Meningktka Kinerja Guru Penjas Sekolah Dasar Kecamatan Binjai Selatan. UNIMED.

Imansyah, F. (2018). Minat Belajar Siswa Pada Pelajaran Penjas Orkes Terhadap Hasil Belajar Pelajaran Penjas Orkes Siswa Sma Negeri Se-Kecamatan Pengandonan. Prosiding Seminar Nasional Program Pascasarjana Universitas Pgri Palembang, Vol 5. No 5.

Irawan, E., Shandi, S. A., \& Salahudin, S. (2020). Manajemen Pembelajaran Guru Pendidikan Jasmani Sekolah Dasar di Kota Bima. JISIP (Jurnal Ilmu Sosial Dan Pendidikan), 4(3).

Jihad, A. (2013). No Title. In Menjadi guru profesional: Strategi meningkatkan kualifikasi dan kualitas guru di era global. Penerbit Erlangga.

Kartowagiran, B. (2011). Kinerja guru profesional (Guru pasca sertifikasi). Jurnal Cakrawala Pendidikan, 3(3).

Librianty, N. (2020). Analisis Kemampuan Guru Dalam Pengelolaan Kelas Pada 
Mata Pelajaran Penjaskes Di Sekolah

Dasar. Jurnal Basicedu, 4(1), 141-148.

Listyarini, E. (2006). Kreativitas Guru

Pendidikan Jasmani Dalam

Pembelajaran Permainan Sepakbola

Disekolah Menengah Pertama. Jurnal

Pendidikan Jasmani Indonesia, 5(1).

Nurmila, J. N. J. (2020). Analisa Sikap Guru Penjas Terhadap Penggunaan Teknologi Informasi dan Komunikasi dalam Pembelajaran Daring di Kecamatan Wonosalam. In Seminar Nasional Keindonesiaan (FPIPSKR), 200-205.

Sugiyono. (2015). Metode Penelitian \& Pengembangan Research And Development. Bandung: Alfabeta.

Tri Irianto dan, \& Arifin, R. dan M. F. (2020). The Relationship of Physical Activities and Student Learning Outcomes of Physical Education. Kinestetik: Jurnal Ilmiah Pendidikan Jasmani, 5(2), 318325.

https://doi.org/https://doi.org/10.33369/ jk.v5i2.16376

Warni, H., Arifin, S., \& Arifin, R. (2021). Karakteristik Pembelajaran Pendidikan Jasmani Olahraga Kesehatan (Pjok) Di Lingkungan Lahan Basah. In Prosiding Seminar Nasional Lingkungan Lahan Basah, 6/1.

Warni, H., Arifin, S., \& Arifin, R. (2020). Problematic Education Physical Students in the Wetlands. 1st South Borneo International Conference on Sport Science and Education (SBICSSE 2019), 8-10.

Wicaksono, G. H. (2019). Kreativitas Guru Penjas Terhadap Proses Pembelajaran Penjas Di Sekolah Menengah Pertama Negeri Sekecamatan Kebumen Kabupaten Kebumen 2018. Jurnal Pendidikan Kesehatan Rekreasi, 5(2), 95-100.

Widiastuti. (2011). Tes Dan Pengukuran Olahraga. PT. Bumi Timur Jaya. 